\title{
Mutations of $p 53$ gene in canine sweat gland carcinomas probably associated with UV radiation
}

\author{
Agnieszka Jasik $^{1 凶}$, Anna Kycko ${ }^{1}$, Monika Olech ${ }^{2}$, Krzysztof Wyrostek $^{3}$, Anna Śmiech ${ }^{4}$, \\ Wojciech Łopuszyński ${ }^{4}$, Iwona Otrocka-Domagała ${ }^{5}$, Mateusz Mikiewicz ${ }^{5}$, Izabella Dolka ${ }^{6}$ \\ ${ }^{1}$ Department of Pathology, ${ }^{2}$ Department of Biochemistry, \\ ${ }^{3}$ Department of Poultry Diseases, National Veterinary Research Institute, 24-100 Puławy, Poland \\ ${ }^{4}$ Department of Pathology, Faculty of Veterinary Medicine, University of Life Sciences in Lublin, 20-612 Lublin, Poland \\ ${ }^{5}$ Department of Pathology, Faculty of Veterinary Medicine, University of Warmia and Mazury, 10-718 Olsztyn, Poland \\ ${ }^{6}$ Department of Pathology, Faculty of Veterinary Medicine, Warsaw University of Life Sciences, 02-776 Warsaw, Poland \\ agnieszka@piwet.pulawy.pl
}

Received: August 13, $2021 \quad$ Accepted: December 9, 2021

\begin{abstract}
Introduction: Apocrine sweat gland carcinomas (ASGCs) are rare malignant skin tumours in dogs and humans. The literature published so far focuses mostly on the clinico-epidemiological aspect of these tumours, but little is known about their pathogenesis. In this study we aimed to determine whether the $p 53$ gene is involved in the carcinogenesis of the apocrine sweat gland in dogs and whether ultraviolet radiation (UV) is related to it. Material and Methods: Forty canine ASGCs were submitted to laser capture microdissection to isolate neoplastic cells, from which DNA was subsequently extracted. PCR amplification and sequencing of p53 exons 2-8 was then performed, followed by computer analysis of the obtained sequences. Results: Sixteen mutations within the $p 53$ gene were found in 13 tumours. The mutations involved $\mathrm{C} \rightarrow \mathrm{T}, \mathrm{T} \rightarrow \mathrm{C}, \mathrm{G} \rightarrow \mathrm{A}$, and $\mathrm{CC} \rightarrow \mathrm{TT}$ transitions, $\mathrm{C} \rightarrow \mathrm{G}$ transversion and adenine deletion, which are gene alteration types known to be related to UV radiation in the process of skin carcinogenesis in humans. Six of the thirteen tumour cases displayed the $\mathrm{C} \rightarrow \mathrm{T}$ transitions in the same location in exon 4 and three of the thirteen cases displayed $\mathrm{T} \rightarrow \mathrm{C}$ in the same location in exon 5. Conclusion: The results of the present study indicate both the participation of the $p 53$ gene and the influence of UV radiation in the formation of ASGCs in dogs.
\end{abstract}

Keywords: dog, apocrine sweat gland carcinoma, $p 53$ gene, mutations, UVR.

\section{Introduction}

Apocrine sweat gland carcinomas (ASGCs) are rare malignant skin tumours which represent approximately $0.7 \%$ to $2.2 \%$ of all skin neoplasms diagnosed in dogs $(3,4,29,56)$. Individual cases of this type of tumour were reported in cats $(14,16,50)$, cattle $(54,61)$, horses $(2,11)$ and a rabbit $(41)$. ASGCs are also very rare in humans, with an incidence rate estimated to range from 0.0049 to 0.0173 per 100,000 patients per year (17). In dogs, these cancers have been found to occur at older age (from 6 to 17 years) in both sexes, mainly in golden retrievers, mixed breeds and German shepherds $(29,56)$. Tumours can grow anywhere on the body, but most frequently on the head, neck, thorax and limbs $(23,29$, $36,56)$. They are usually aggressive, with a tendency to local recurrence and metastasis to the regional lymph nodes, lungs, liver, bone and bone marrow via lymphatic and intravascular invasion both in humans $(4,36,48,65)$ and dogs $(3,19,22,42,56)$. The available literature describing canine ASGCs provides reports which focus mostly on the morphological appearance and epidemiological data, whereas little is known about the aetiology and molecular alterations underlying the development of these cancers.

Carcinogenesis has been described as a multi-stage process and the result of many interrelated genetic changes associated with the influence of one or multiple specific genotoxic aetiological factors. The pathogenesis of approximately $50 \%$ of human skin cancer cases has been associated with ultraviolet radiation (UVR), which has been found to cause characteristic alterations within the $p 53$ tumour suppressor gene (12). These alterations have been detected in normal sun-exposed skin $(1,5$, 34 ), in precancerous lesions such as actinic keratosis and Bowen's disease, in squamous and basal cell carcinomas 
(25) and, less frequently, in melanomas. Therefore, UVR is considered to be an early and specific carcinogenic factor in the development of skin cancers in humans $(1,5,12,25,27,35,52,54,65,66)$. According to the available literature, the sun emits three types of UVR: UVRA (320-400 nm), UVRB (280-320 nm) and UVRC (100-280 nm), which each damage DNA in a different way. In the skin carcinogenesis induced by UVRB, the formation of photoproducts such as cyclobutane pyrimidine dimers and pyrimidine (6-4)-pyrimidone leads to highly specific mutations arising, mainly single $\mathrm{C} \rightarrow \mathrm{T}$ and $\mathrm{G} \rightarrow \mathrm{A}$ and tandem $\mathrm{CC} \rightarrow \mathrm{TT}$ and $\mathrm{GG} \rightarrow \mathrm{AA}$ transitions, known as the "genetic fingerprint of UVR" $(5,10,25,52)$. The result of harmful UVRA exposure is the formation of reactive oxygen species (ROS), which leads to the appearance of several transitions similar to those caused by UVRB $(\mathrm{C} \rightarrow \mathrm{T}$ and $\mathrm{G} \rightarrow \mathrm{A})$ and less commonly to other mutations, such as the $\mathrm{T} \rightarrow \mathrm{C}$ transition and the $\mathrm{T} \rightarrow \mathrm{G}$ and $\mathrm{C} \rightarrow \mathrm{A}$ transversions. The third type of radiation, UVRC, is highly mutagenic, but does not reach the Earth's surface, because it is almost completely blocked by the stratospheric ozone layer (52). Scientific literature widely describes UVR as one of the factors responsible for the development of squamous cell carcinomas $(1,5,27,65)$, basal cell carcinomas $(5,27,65)$, malignant melanomas, and according to some authors, sweat gland carcinomas in humans (6). In dogs, exposure to UV light can cause squamous cell carcinoma, melanoma, haemangioma and haemangiosarcoma (56), but this statement is based more on clinico-epidemiological and immunohistochemical studies than molecular investigations $(13,55,61)$. To the best of our knowledge, among the reports of p53 mutations in dogs published so far $(20,24,37-39,44)$, none confirms UVR influence on canine skin carcinogenesis.

The main purpose of the present study was to investigate whether the $p 53$ gene is involved in the process of ASGC carcinogenesis in dogs, and whether the potential p53 mutations in these cancers could be related to the influence of UVR.

\section{Material and Methods}

Material. The material for the study consisted of 40 archival paraffin blocks of canine ASGC tissues collected from national veterinary pathology laboratories in Poland between 2009 and 2014. The ASGCs accounted for $0.92 \%$ of all canine skin tumours diagnosed in these laboratories during that time.

Laser capture microdissection. For molecular analysis, the paraffin blocks were cut into $4 \mu \mathrm{m}$ sections and stained with haematoxylin and eosin without coverslips. In order to visualise and select neoplastic cells under a microscope, a drop of xylene was applied to individual sections subjected to microdissection (Fig. 1). The laser capture microdissection was performed using an Arcturus XT system (Life Technologies,
Carlsbad, CA, USA). The selected tumour cells were captured using a near-infrared laser pulse and transferred onto a macro cap (CapSure ${ }^{\circledR}$ Macro LCM, cat. no. LCM02; Life Technologies). DNA was extracted from the cells on the cap after overnight incubation with proteinase $\mathrm{K}$ extraction buffer at $56^{\circ} \mathrm{C}$, using the Arcturus ${ }^{\circledR}$ PicoPure ${ }^{\circledR}$ DNA Extraction Kit (cat. no. KIT0103; Life Technologies) and $0.5 \mathrm{ml}$ of autoclaved GeneAmp thin-walled reaction tubes (cat. no. N8010611; Applied Biosystems, Foster City, CA, USA). Following proteinase $\mathrm{K}$ digestion, the buffer was incubated at $95^{\circ} \mathrm{C}$ for $10 \mathrm{~min}$ and DNA was isolated and eluted in $20 \mu \mathrm{L}$ of the buffer following the kit manufacturer's instructions.

PCR amplification and sequencing. For PCR amplification, samples of DNA extracted from the microdissected neoplastic tissues and the control DNA extracted from blood leucocytes of three healthy dogs with confirmed wild-type sequences of each exon of $p 53$ were used.

Oligonucleotide primers used in the PCR targeted conservative regions of canine $p 53$ (exons $5,6,7,8$ ) and the exons outside of these regions (exons 2, 3, 4, 9, 10, 11). The primer sets were designed for each exon separately according to published literature (8). The reaction mixture at a total volume of $25 \mu \mathrm{L}$ contained $50 \mathrm{ng}$ of DNA, $2.5 \mu \mathrm{L}$ of polymerase buffer (10x Taq buffer: $100 \mu \mathrm{M}$, Tris- $\mathrm{HCl}, \mathrm{pH} 8.8 ; 500 \mu \mathrm{M} \mathrm{KCl}$; Fermentas, Vilnius, Lithuania), $2.0 \mathrm{mM} \mathrm{MgCl} 2\left(25 \mathrm{mM} \mathrm{MgCl}_{2}\right.$ stock; Fermentas), $400 \mu \mathrm{M}$ dNTPs (10 mM dNTP mix stock; Fermentas), $5 \mu \mathrm{M}$ of each primer and 3 units of Taq polymerase (Taq polymerase 1 unit/ $\mu \mathrm{L}$ stock; Fermentas). The PCR amplification conditions were as follows: initial denaturation at $94^{\circ} \mathrm{C}$ for $10 \mathrm{~min}$ followed by 45 cycles of $30 \mathrm{~s}$ denaturation at $94^{\circ} \mathrm{C}, 60 \mathrm{~s}$ primer hybridisation at $58^{\circ} \mathrm{C}$ and $60 \mathrm{~s}$ elongation at $72^{\circ} \mathrm{C}$. Amplification was completed with elongation at $72^{\circ} \mathrm{C}$ for $5 \mathrm{~min}$. The temperature profile and the composition of the reaction mixture were identical for all exons (2-11) of the $p 53$ gene.

Unincorporated primers and dNTPs were removed from the PCR products of individual exons of the $p 53$ gene and the products intended for sequencing were purified using ExoSap-IT (USB Affymetrix, Santa Clara, CA, USA) or Exo-BAP (EURx, Gdańsk, Poland) kits, which called for incubation in a Veriti 96-Well FAST Thermal Cycler (Applied Biosystems, Foster City, CA, USA) at $37^{\circ} \mathrm{C}$ for $15 \mathrm{~min}$ and then at $80^{\circ} \mathrm{C}$ for $15 \mathrm{~min}$. To improve the sequencing quality and accuracy additional purification was performed using a QIAquick Gel Extraction Kit (Qiagen, Hilden, Germany) following the kit manufacturer's instructions. Due to the length of the PCR product of individual exons being between $74 \mathrm{bp}$ (exon 3) and 204 bp (exon 4), 1-3 ng of the template was used for sequencing. Two separate cycles of sequencing reactions were carried out (one forward and one reverse) for each of the 11 exon specific products using a Terminator v 3.1 Cycle Sequencing Kit (Applied Biosystems). 


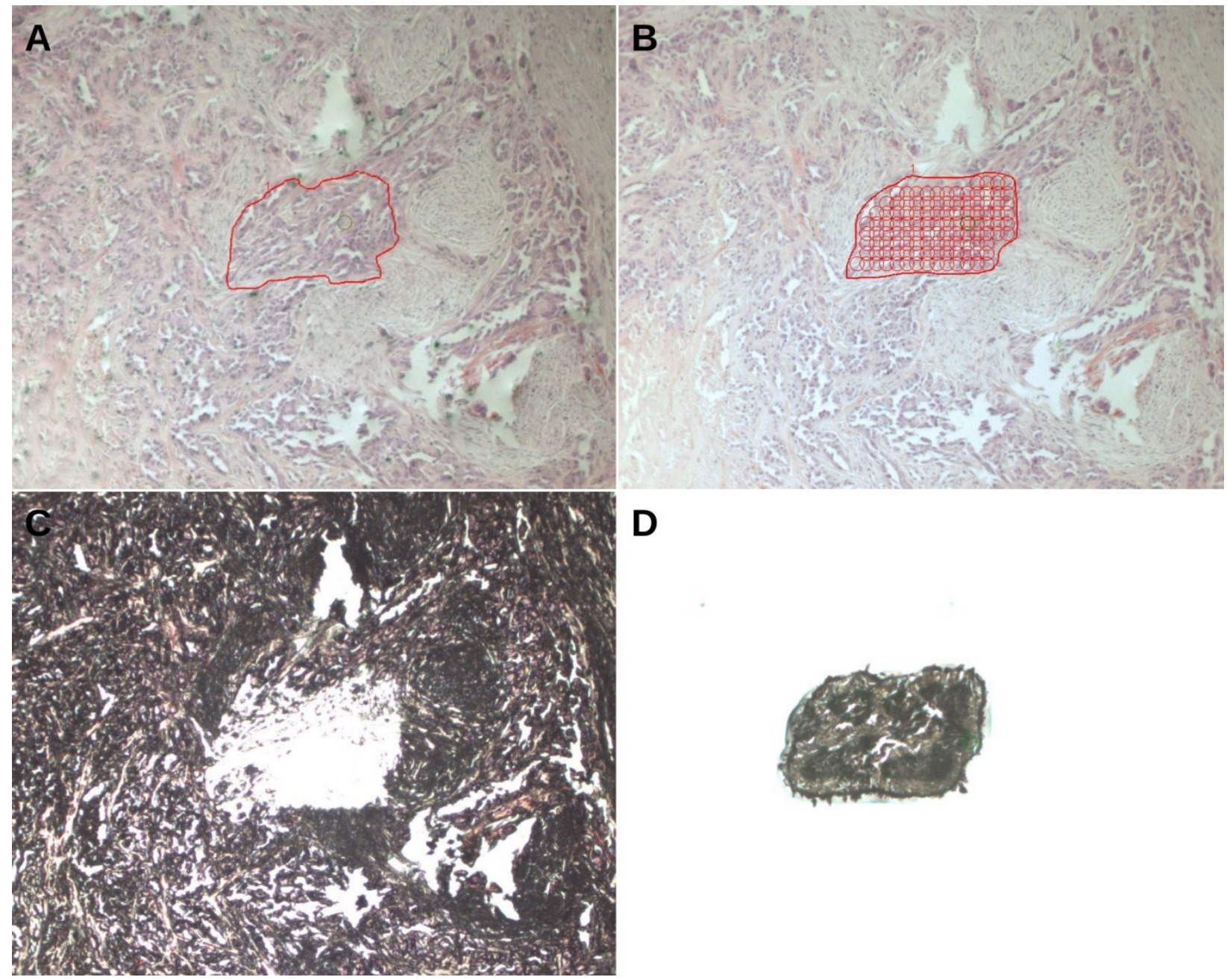

Fig. 1. Example images of the laser capture microdissection of tumour cells acquired using Arcturus XT operating software (10× objective). A - Haematoxylin and eosin stained section, covered with xylene for visualisation, showing cystic/papillary type apocrine sweat gland carcinoma before microdissection, with the area containing tumour cells marked with a red line. B - The same section with marked tumour cells and laser infrared spots (IR spots). C - The same section after xylene evaporation and the microdissection of the marked cells. D - Tumour cells transferred to the macro cap after laser capture microdissection

Sequencing reaction conditions were as follows: initial denaturation at $96^{\circ} \mathrm{C}$ for $60 \mathrm{~s}$ followed by 25 cycles of denaturation at $96^{\circ} \mathrm{C}$ for $10 \mathrm{~s}$, primer hybridisation at $50^{\circ} \mathrm{C}$ for $5 \mathrm{~s}$ and elongation at $60^{\circ} \mathrm{C}$ for 4 min using the Veriti 96-Well FAST Thermal Cycler. The pre-sequencing products were purified using a BigDye X Terminator Purification Kit (Applied Biosystems) and then capillary electrophoresis was performed using an 8-capillary Hitachi 3500 Genetic Analyser sequencer (Applied Biosystems). The obtained sequences were trimmed and analysed using Geneious Pro 5.3 software (Biomatters, Auckland, New Zealand). To exclude Taq polymerase errors, a sequence analysis was performed twice for each of the exons of the $p 53$ gene. The consensus sequences corresponding to each amplified fragment were generated from each sample and compared with the sequence of canine control samples of p53 (K1) and with the canine and human sequences of $p 53$ from GenBank at the National Center for Biotechnology Information (GenBank canine sequence accession numbers U62133 and AB020761 and human sequence accession number K03199).
Sequences were aligned using the Geneious alignment module.

\section{Results}

The study yielded 16 p53 mutations to detection confirmed in 13 ASGC samples, which constituted $31.7 \%$ of all the examined ASGCs (Table 1). Sequence analysis of the remaining 27 samples revealed mutation less p53 genes. Among the 16 mutations, 11 missense point mutations, 1 tandem mutation, 3 silent point mutations and 1 single deletion were identified. The detected mutations were located both within the highly conserved region of the $p 53$ gene (exons 5-8) and outside it (exon 4). The majority of the identified mutations consisted of $\mathrm{C} \rightarrow \mathrm{T}, \mathrm{T} \rightarrow \mathrm{C}$ and $\mathrm{G} \rightarrow$ A single transitions. There was also one $\mathrm{CC} \rightarrow \mathrm{TT}$ double transition, one $\mathrm{C} \rightarrow \mathrm{G}$ transversion and one adenine deletion (Table 1). Six out of seven samples with mutations in exon 4 showed a specific substitution of phenylalanine for serine at position 90 of the $p 53$ protein 
(Fig. 2), while three out of five samples with mutations in exon 5 showed substitution of alanine for valine at position 157 of the protein (Fig. 3). Mutations of p53 were identified mainly in solid ASGCs, less frequently in ductal ASGCs and papillary ASGCs, and in single incidences in cystic/papillary and tubular ASGCs and as a carcinosarcoma (Table 1). Tumours in which the mutations of the p53 gene were found were mainly located in the chest and forelimb. The age of the dogs with p53-mutated ASGCs ranged from 5 to 12 years with an average of 8.41 years, and mixed-breed dogs were most affected.

Table 1. Mutations in the $p 53$ gene in canine ASGC

\begin{tabular}{|c|c|c|c|c|c|c|c|}
\hline $\begin{array}{l}\text { Sample } \\
\text { no. }\end{array}$ & Histology* & Breed & $\begin{array}{l}\text { Age } \\
\text { (years) }\end{array}$ & Body location & Exon & Codon $^{\dagger}$ & Mutation (amino acid) \\
\hline 180 & Papillary ASGC & - & 5 & $\begin{array}{c}\text { Chest } \\
\text { (rib area) }\end{array}$ & 5 & 157 & $\begin{array}{l}\mathrm{gTc} \rightarrow \mathrm{gCc} \\
(\mathrm{Val} \rightarrow \text { Ala })\end{array}$ \\
\hline 188 & Papillary ASGC & $\begin{array}{l}\text { German } \\
\text { shepherd }\end{array}$ & 6 & $\begin{array}{l}\text { Forelimb } \\
\text { (arm area) }\end{array}$ & 8 & 264 & $\begin{array}{c}\mathrm{aAc} \rightarrow \mathrm{a}-\mathrm{c} \\
\text { reading frame shift }\end{array}$ \\
\hline 190 & Solid ASGC & Mixed breed & 8 & $\begin{array}{c}\text { Neck } \\
\text { (side neck area) }\end{array}$ & 5 & 178 & $\begin{array}{l}\mathrm{caC} \rightarrow \mathrm{caT} \\
(\mathrm{His}=\mathrm{His})\end{array}$ \\
\hline 191 & Ductal ASGC & Mixed breed & 10 & $\begin{array}{c}\text { Chest } \\
\text { (scapular area) }\end{array}$ & 5 & 149,150 & $\begin{array}{c}\text { tcCCca } \rightarrow \text { tcTTca } \\
(\text { Ser }=\text { Ser; Pro }>\text { Ser })\end{array}$ \\
\hline 193 & Solid ASGC & Dachshund & 9 & $\begin{array}{c}\text { Forelimb } \\
\text { (axillary area) }\end{array}$ & 5 & 157 & $\begin{array}{l}\mathrm{gTc} \rightarrow \mathrm{gCc} \\
(\mathrm{Val} \rightarrow \text { Ala })\end{array}$ \\
\hline 194 & Tubular ASGC & $\begin{array}{c}\text { Giant } \\
\text { schnauzer }\end{array}$ & - & Finger & $\begin{array}{l}4 \\
6\end{array}$ & $\begin{array}{c}63 \\
123 \\
214\end{array}$ & $\begin{array}{c}\mathrm{gcT} \rightarrow \mathrm{gcC} \\
(\mathrm{Ala}=\mathrm{Ala}) \\
\mathrm{aCt} \rightarrow \mathrm{aGt} \\
(\mathrm{Thr} \rightarrow \mathrm{Ser}) \\
\mathrm{aCt} \rightarrow \mathrm{aGt} \\
(\mathrm{Thr} \rightarrow \mathrm{Ser})\end{array}$ \\
\hline 201 & Ductal ASGC & Mixed breed & 12 & $\begin{array}{c}\text { Head } \\
\text { (auricle area) }\end{array}$ & 5 & 157 & $\begin{array}{c}\mathrm{gTc} \rightarrow \mathrm{gCc} \\
(\mathrm{Val} \rightarrow \text { Ala })\end{array}$ \\
\hline 212 & Papillary ASGC & Mixed breed & 11 & - & 4 & 90 & $\begin{array}{c}\mathrm{tCc} \rightarrow \mathrm{tTc} \\
(\mathrm{Ser} \rightarrow \mathrm{Phe})\end{array}$ \\
\hline 217 & Ductal ASGC & Mixed breed & 5 & - & 4 & 90 & $\begin{array}{c}\mathrm{tCc} \rightarrow \mathrm{tTc} \\
(\mathrm{Ser} \rightarrow \mathrm{Phe})\end{array}$ \\
\hline 219 & $\begin{array}{c}\text { Cystic, papillary } \\
\text { ASGC }\end{array}$ & Mixed breed & 5 & $\begin{array}{c}\text { Pelvis } \\
\text { (gluteal area) }\end{array}$ & 4 & 90 & $\begin{array}{c}\mathrm{tCc} \rightarrow \mathrm{tTc} \\
(\mathrm{Ser} \rightarrow \mathrm{Phe})\end{array}$ \\
\hline 220 & Solid ASGC & - & 11 & $\begin{array}{c}\text { Pelvis } \\
\text { (anal area) }\end{array}$ & 4 & 90 & $\begin{array}{c}\mathrm{tCc} \rightarrow \mathrm{tTc} \\
(\mathrm{Ser} \rightarrow \mathrm{Phe})\end{array}$ \\
\hline 221 & Solid ASGC & French bulldog & 11 & - & 4 & 90 & $\begin{array}{c}\mathrm{tCc} \rightarrow \mathrm{tTc} \\
(\mathrm{Ser} \rightarrow \mathrm{Phe})\end{array}$ \\
\hline 222 & $\begin{array}{c}\text { Carcinosarcoma } \\
\text { ASG }\end{array}$ & $\begin{array}{l}\text { Miniature } \\
\text { schnauzer }\end{array}$ & 8 & $\begin{array}{c}\text { Chest } \\
\text { (rib area) }\end{array}$ & 4 & 90 & $\begin{array}{c}\mathrm{tCc} \rightarrow \mathrm{tTc} \\
(\mathrm{Ser} \rightarrow \mathrm{Phe})\end{array}$ \\
\hline
\end{tabular}

*ASGC - apocrine sweat gland carcinoma; ASG - apocrine sweat gland; † corresponding to human p53 gene

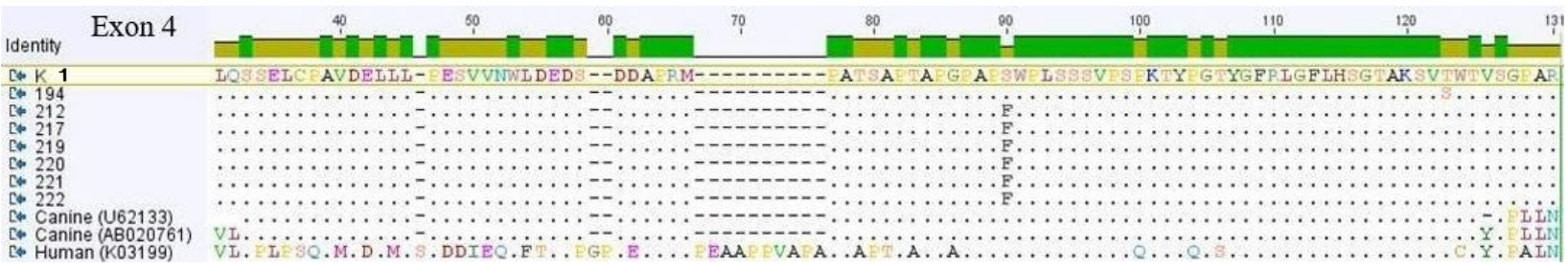

Fig. 2. Alignment of the amino acid sequence of exon 4 of the $p 53$ protein of the canine control (K1) sample and tested samples of apocrine sweat gland carcinomas with canine (U62133, AB020761) and human (K03199) amino acid reference sequences of the $p 53$ protein 


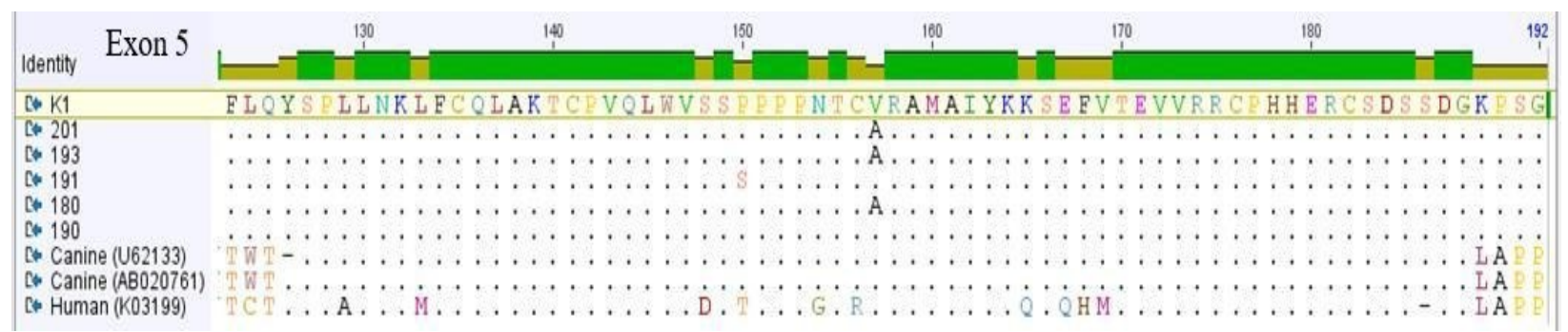

Fig. 3. Alignment of the amino acid sequence of exon 5 of the $p 53$ protein of the canine control (K1) sample and tested samples of apocrine sweat gland carcinomas with canine (U62133, AB020761) and human (K03199) amino acid references sequence of the $p 53$ protein

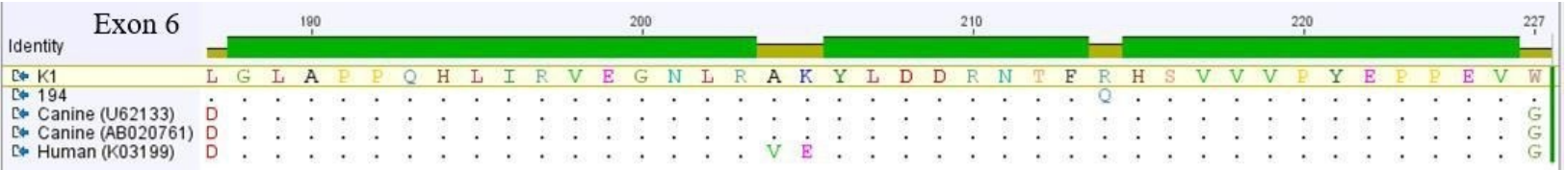

Fig. 4. Alignment of the amino acid sequence of exon 6 of the $p 53$ protein of the canine control (K1) sample and tested samples of apocrine sweat gland carcinoma with canine (U62133, AB020761) and human (K03199) amino acid reference sequences of the $p 53$ protein

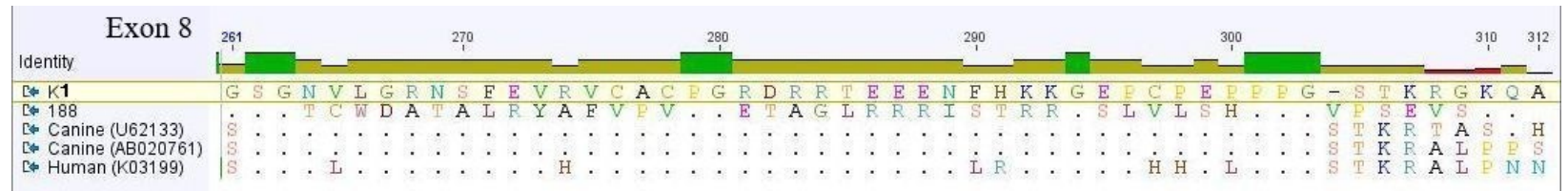

Fig. 5. Alignment of the amino acid sequence of exon 8 of p53 of the canine control (K1) sample and tested samples of apocrine sweat gland carcinomas with canine (U62133, AB020761) and human (K03199) amino acid reference sequences of the $p 53$ protein

\section{Discussion}

Research on ASGCs published so far has not clearly defined which mechanisms are responsible for the formation of these tumours, although several publications are available describing mutations of the p53 gene in single cases of ASGCs in humans (6) and dogs (20) and one report exists on the loss of heterozygosity confined to the $17 \mathrm{p}$ chromosome arm in humans (58). In the present study, 13 out of 40 canine ASGCs displayed $p 53$ gene alterations such as single $\mathrm{C} \rightarrow \mathrm{T}$ and $\mathrm{T} \rightarrow \mathrm{C}$ transitions and $\mathrm{CC} \rightarrow \mathrm{TT}$ double transition, which, according to previous reports, are characteristic of and specific to the involvement of UVR in skin carcinogenesis. The lack of $p 53$ mutations in the remaining cases suggests that this gene was not involved in the carcinogenesis of these tumours; putatively, these neoplasms are associated with other genes such as $H$-ras or K-ras (6).

The most prominent finding in our study was the detection of the TCC $\rightarrow$ TTC missense mutation at codon 90 changing serine to phenylalanine. It was common to 6 out of 13 ASGCs displaying p53 mutations. Although this was the highest number of cases sharing the same p53 mutation, there was not enough data available to determine any association of the mutation to breed, age, sex, tumour location or histological type. We failed to find any reports in the available literature on this mutation in any type of tumour. The GCT $\rightarrow$ GCC silent mutation found in another case at codon 63 has also not been previously reported to the best of our knowledge; however, there were other mutations at this codon revealed in human cancer, such as cytosine deletion considered to be a marker in oral squamous cell carcinoma $(32,40,57)$ and the missense mutation changing alanine to proline in synovial sarcoma (9). Both codons 63 and 90 are located within a signalling proline-rich domain of the p53 protein between amino acids 61 and 94. The high proline content in this domain, especially sequence PXXP motifs (where $\mathrm{P}$ represents proline and $\mathrm{X}$ any amino acid), plays a critical role in the transmission of antiproliferative signals in response to DNA-damaging factors, leading to apoptosis (21).

At codon 157 in three ASGCs in our study, the missense mutation GTC $\rightarrow$ GCC changing valine to alanine was detected, which was consistent with the $p 53$ mutation described in canine osteosarcoma (26). This codon is located in the $\beta$-sandwich strand $\mathrm{S} 4$ of the DNA-binding core domain at residues 94-321, p53C, which plays a key role in the folding and stability of this domain of the $p 53$ gene (21) and is often mutated in colorectal, breast, liver, lung and ovary cancers in humans $(30,31)$. Single silent mutations associated with UVR at p53 codon 157 were described in the stratum granulosum of squamous cell carcinoma (1) and in sporadic basal cell carcinoma cases (33) in humans. Studies on colorectal tumours published by Takata et al. (58) revealed single missense mutations and deletion/ insertion of several nucleotides, which resulted in a frameshift and truncated $p 53$ protein (59). Interestingly, the most common mutation at codon 157 documented by other authors is a valine to phenylalanine transition, which represents $77 \%$ of all mutations detected in this codon. This type of mutation located within the $\beta$-sandwich region causes global effects on the DNA-binding core domain and loop-sheet-helix motif, reducing the thermodynamic stability of the $p 53$ protein and causing 
its unfolding at body temperature both in vitro and in vivo, and is classified as a globally denatured mutant $(7,47)$. Codon 157 is also considered to be a hotspot region associated with hepatoblastoma in children (45), a marker of poor prognosis in patients with hepatocellular carcinoma, and one of the most frequently mutated hotspot codons in smoking lung cancer patients $(15,51,62,64)$. Additionally, it has been found that cells containing alterations at codon 157 show medium radiosensitivity (46).

The same silent mutation at codon $178(\mathrm{CAC} \rightarrow \mathrm{CAT})$ that was detected in one case in our study occurred in single cases of human sporadic basal cell carcinoma, nevoid basal cell carcinoma syndrome (Gorlin-Goltz syndrome) (33) and testicular carcinoma in situ (28). Several other mutations at codon 178 were detected in basal cell carcinoma (changing histidine to asparagine) (65) and in radiation dermatitis where the $\mathrm{C} \rightarrow \mathrm{A}$ transition led to the substitution of glutamine for histidine (27). Moreover, this codon falls in the hotspot regions in basal cell carcinomas in patients with the inherited disease of deficient DNA repair xerodema pigmentosum (12).

The other $p 53$ gene alterations revealed in the present study included the ACT $\rightarrow$ AGT missense mutation at codon 123, the $\mathrm{CC} \rightarrow \mathrm{TT}$ tandem mutation at codons 149-150 and the $\mathrm{AAC} \rightarrow \mathrm{A}-\mathrm{C}$ deletion at codon 264 causing Asn to Tyr frameshift changing. To the best of our knowledge, none of these mutations have previously been described in any tumour. The only published studies on $p 53$ codon 123 were performed on the Saos-2 human osteosarcoma cell line and revealed that cells with the threonine to alanine change at this location became highly radiosensitive (46). With regard to the alteration at codons $149-150$, a TCC $\rightarrow$ TCT silent mutation was revealed at codon 149 in our study, in contrast to the findings of Hsu et al. (18). Those researchers detected a missense mutation at this gene position changing serine to phenylalanine in patients with precancerous Bowen's disease caused by UVR and chronic exposure to a high level of arsenic contamination in drinking water (18). Additionally, another missense mutation at codon 149 (TCC $\rightarrow$ CCC) changing serine to proline was documented in oral squamous cell carcinomas (43), whereas in a report on colorectal cancer by Tang et al. (59) there was an insertion of thymine at this location of the p53 gene, generating a frameshift that resulted in a truncated $p 53$ protein. At codon 150 there was a missense mutation identified in the present study, which has not been detected in any species so far. According to some authors, UVRA penetrates the skin deeper than UVRB $(49,52)$, which suggests that UVRA might be responsible for carcinogenesis in canine sweat glands due to their location in the skin. However, the types of mutation described in our study appear to be associated with the effect of both UVRB (C $\rightarrow \mathrm{T}, \mathrm{G} \rightarrow \mathrm{A}$ and $\mathrm{CC}$ $\rightarrow \mathrm{TT}$ ) and UVRA ( $\rightarrow \mathrm{C}, \mathrm{C} \rightarrow \mathrm{G}$ and single deletions) accounting for $60 \%$ and $40 \%$ of all mutations detected, respectively.
In conclusion, $31.7 \%$ of the examined canine ASGCs have been confirmed to be affected by $p 53$ mutations, the majority of which, including the mutation detected in six cases in exon 4, have never been reported in any tumour. Moreover, the characteristics of all the detected mutations are consistent with those of UVRinduced gene alterations. Our results may therefore indicate the involvement of both the $p 53$ gene and UVA and UVB radiation in the formation of ASGCs in dogs. Moreover, these results revealed new and important mutations associated with the function of the $p 53$ gene.

Conflict of Interests Statement: The authors declare that there is no conflict of interests regarding the publication of this article.

Financial Disclosure Statement: The research and the article were financed by the Polish National Science Centre, grant no. 2012/05/D/NZ5/01841.

Animal Rights Statement: None required.

Acknowledgements: We would like to thank technicians Anna Wijaszka and Małgorzata Zaborna for technical support in slide preparation for microdissection, DNA isolation and PCR amplification.

\section{References}

1. Agar N.S., Halliday G.M., Barnetson R.StC., Ananthaswamy H.N., Wheeler M., Jones A.M.: The basal layer in human squamous tumors harbors more UVA than UVB fingerprint mutations. A role for UVA in human skin carcinogenesis. PNAS 2004, 101, 4954-4959, doi: 10.1073/pnas.0401141101.

2. Anderson W.I., Scott D.W., Crameri F.M.: Two rare cutaneous neoplasms in horses: apocrine gland adenocarcinoma and carcinosarcoma. Cornell Vet 1990, 80, 339-345.

3. Baharak A., Reza K., Shahriar D., Omid A., Daruoosh V., Nasrin A.: Metastatic apocrine sweat gland adenocarcinoma in a terrier dog. Asian Pac J Trop Biomed 2012, 2, 670-672, doi: 10.1016/S2221-1691(12)60118-X

4. Bahl A., Sharma D.N., Julka P.K., Das A., Rath G.K.: Sweat gland carcinoma with lung metastases. J Cancer Res Ther 2006, 2, 209-211, doi: 10.4103/0973-1482.29836.

5. Benjamin C.L., Ananthaswamy H.N.: p53 and the pathogenesis of skin cancer. Toxicol Appl Pharmacol 2007, 224, 241-248, doi: 10.1016/j.taap.2006.12.006.

6. Biernat W., Peraud A., Woźniak L., Ohgaki H.: p53 mutations in sweat gland carcinomas. Int J Cancer 1998, 76, 317-320, doi: 10.1002/(sici)1097-0215(19980504)76:3<317::aid-ijc5>3.0.co;2-y.

7. Calhoun S., Daggett V.: Structural effect of the L145Q, V157F, and R282W cancer-associated mutations in the p53 DNA-binding core domain. Biochemistry 2011, 50, 5345-5353, doi:10.1021/bi200192j.

8. Chu L.L., Rutteman G.R., Kong J.M., Ghahremani M., Schmeing M., Misdor W., van Garderen E., Pelletier J.: Genomic organization of the canine p53 gene and its mutational status in canine mammary neoplasia. Breast Canc Res Treat 1998, 50, 11-25, doi: 10.1023/A:1006010526813.

9. Das P., Kotilingam D., Korchin B., Liu J., Yu D., Lazar A.J., Pollock R.R., Lev D.: High prevalence of p53 exon 4 mutations in soft tissue sarcoma. Cancer 2007, 109, 2323-2333,10.1002/cncr.22680.

10. Ferenc T., Pacholczyk M., Czernicki J.: The effect of solar ultraviolet radiation (UVR) on a human organism. Part II: 
mutagenic activity and repair of DNA lesion. Acta Balneol 2014, 2, 82-87.

11. Ghasemi S., Sardari K., Movassaghi A.R.: Aapocrine sweat gland ductal carcinoma in a 5-years-old Arabian stallion. Comp Clin Pathol 2017, 26, 1399-1402, doi: 10.1007/s00580-017-2535-y.

12. Giglia-Mari G., Sarasin A.: TP53 mutations in human skin cancers. Hum Mutat 2003, 21, 217-228, doi: 10.1002/hum.10179.

13. Hargis A.M., Thomassen R.W., Phemister R.D.: Chronic dermatosis and cutaneous squamous cell carcinoma in the beagle dog. Vet Pathol 1977, 14, 218-228, doi: 10.1177/030098587701400304.

14. Haziroglu R., Haligur M., Keles H.: Histopathological and immunohistochemical studies of apocrine sweat gland adenocarcinomas in cats. Vet Comp Oncol 2014, 12, 85-90, doi: 10.1111/j.1476-5829.2012.00321.x

15. Hernandez-Boussard T.M., Hainaut P.: A specific spectrum of p53 mutations in lung cancer from smokers: Review of mutations compiled in the IARC p53 database. Environ Health Perspect 1998, 106, 385-391, doi: 10.1289/ehp.98106385.

16. Herráez P., Rodríguez F., Ramírez G., Aguirre-Sanceledonio M., Castro A., Espinosa de los Monteros A.: Multiple primary digital apocrine sweat gland carcinosarcoma in a cat. Vet Rec 2005, 157, 356-358, doi: 10.1136/vr.157.12.356.

17. Hollowell K.L., Agle S.C., Zervos E.E., Fitzgerald T.L.: Cutaneous apocrine adenocarcinoma: defining epidemiology, outcomes, and optimal therapy for a rare neoplasm. J Surg Oncol 2012, 105, 415-419, doi: 10.1002/jso.22023.

18. Hsu C.-H., Yang S.-A., Wang J.-Y., Yu H.-S., Lin S.-R.: Mutational spectrum of p53 gene in arsenic-related skin cancers from the blackfoot disease endemic area of Taiwan. Br J Cancer 1999, 80, 1080-1086, doi: b10.1038/sj.bjc.6690467.

19. Itoh T., Nishi A., Uchida K., Chambers J., Shii H.: Clinicopathological features of apocrine sweat gland carcinoma treated with surgical excision in five dogs. Jpn J Vet Anesth Surg 2015, 46, 43-47, doi: 10.2327/jjvas.46.43.

20. Jasik A., Reichert M.: New p53 mutations in canine skin tumours. Vet Rec 2011, 169, 684-684, doi: 10.1136/vr.100232.

21. Joerger A.C., Fersht A.R.: Structural biology of the tumor suppressor p53. Annu Rev Biochem 2008, 77, 557-582, doi: 10.1146/annurev.biochem.77.060806.091238

22. Jung Y.-Ch., Woo G.-H., Yun Y.-M., Kim J.-H.: Concurrence of apocrine carcinoma, mammary gland tumors and bladder transitional cell carcinoma in dog. J Vet Clin 2016, 33, 74-79, doi: 10.17555/jvc.2016.02.33.1.74.

23. Kalaher K.M., Anderson W.I., Scott D.W.: Neoplasms of the apocrine sweat glands in 44 dogs and 10 cats. Vet Rec 1998, 127, 400-403, doi: 10.1136/VR.127.16.400.

24. Kanaya N., Okuda M., Toyama N., Oikawa T., Inokuma H., Morimoto M., Hayashi T., Une S., Nakaichi M., Taura Y., Tsujimoto H., Onishi T.: Detection of the anti-p53 antibodies in dogs with tumors. J Vet Med Sci 2002, 64, 973-979, doi: 10.1292/jvms.64.973.

25. Kapka-Skrzypczak L., Dudra-Jastrzębska M., Czajka M., Raszewska-Famielec M., Popek S., Sawicki K., Kruszewski M.: Clinical characteristics and molecular basis of skin tumors (in Polish). Hygeia Public Health 2014, 49, 39-45.

26. Kirpensteijn J., Kik M., Teske E., Rutteman G.R.: TP53 mutations in canine osteosarcoma. Vet Surg 2008, 37, 454-460, doi: 10.1111/j.1532-950X.2008.00407.x.

27. Kubo Y., Urano Y., Yoshimoto K., Iwahana H., Fukuhara K., Arase S., Itakura M.: p53 gene mutations in human skin cancers and precancerous lesions: comparison with immunohistochemical analysis. J Invest Dermatol 1994, 102, 440-444, doi: 10.1111/1523-1747.ep12373002.

28. Kuczyk M.A., Serth J., Bokemeyer C., Jonassen J., Machtens S., Werner M., Jonas U.: Alteration of the p53 tumor suppressor gene in carcinoma in situ of the testis. Cancer 1996, 78, 1958-1966, doi: 10.1002/(sici)1097-0142(19961101)78:9<1958::aidcncr17>3.0.co;2-X.

29. Kycko A., Jasik A., Bocian Ł., Otrocka-Domagała I., Mikiewicz M., Śmiech A., Łopszyński W., Dolka I., Nowak M., Madej A.A.: Epidemiological and histopathological analysis of 40 apocrine sweat gland carcinomas in dogs: a retrospective study. J Vet Res 2016, 60, 331-337, doi: 10.1515/jvetres-2016-0050.

30. Lai H., Lin L., Nadij M., Lai S., Trapido E., Meng L.: Mutations in the p53 tumor suppressor gene and early onset breast cancer. Cancer Biol Ther 2002, 1, 31-36, doi: 10.4161/cbt.1.1.37.

31. Lasky T., Silbergeld E.: P53 mutations associated with breast, colorectal, liver, lung and ovarian cancers. Environ Health Perspect 1996, 104, 1324-1331, doi: 10.1289/ehp.961041324.

32. Liao P.-H., Chang Y.-Ch., Huang M.-F., Tai K.-W., Chou M.-Y.: Mutation of p53 gene codon 63 in saliva as a molecular marker for oral squamous cell carcinomas. Oral Oncol 2000, 36, 272-276, doi: 10.1016/S1368-8375(00)00005-1.

33. Ling G., Ahmadian A., Persson Å., Undén A.B., Afink G., Williams C., Uhlén M., Toftgård R., Lundeberg J., Pontén F.: PATCHED and p53 alterations in sporadic and hereditary basal cell cancer. Oncogene 2001, 20, 7770-7778, doi: 10.1038/sj.onc.1204946.

34. Ling G., Persson Å., Berne B., Uhlén M., Lundeberg J., Pontén F.: Persistent p53 mutations in single cells from normal human skin. AJP, 2001, 159, 1247-1253, doi: 10.1016/S0002-9440(10)62511-4.

35. Lu C., Fuchs E.: Sweat gland progenitors in development, homeostasis, and wound repair. Cold Spring Harb Perspect Med 2014, 4, a015222, doi: 10.1101/cshperspect.a015222.

36. Martins Y.N.F., Sampaio R.A.G., Barbosa M.J.S., de Gois D.D., da Silva Neto J.F., Franco C.I.Q., Lucena R.B.: Eccrine and apocrine carcinoma in dogs (in Portuguese) Acta Scientiae Veterinariae 2020, 48, 502, doi: 10.22456/1679-9216.100610.

37. Mayr B., Reifinger M., Alton K.: Novel canine tumour suppressor gene p53 mutations in cases of skin and mammary neoplasms. Vet Res Commun 1999, 23, 285-291, doi: 10.1023/a:1006314903272.

38. Mayr B., Schaffner W., Botto I., Reifinger M., Loupal G.: Canine tumour suppressor gene p53 - mutation in a case of adenoma of circumanal gland. Vet Res Commun 1997, 21, 369-373. doi: 10.1023/a:1005820607258

39. Mayr B., Schellander K., Schleger W., Reifinger M.: Sequence of an exon of the canine p53 gene-mutation in a papilloma. Br Vet J 1994, 150, 81-84, doi: 10.1016/S0007-1935(05)80099-5.

40. Mewara A., Gadbali A.R., Patil S., Chaudhary M., Chavhan D.: C-deletion mutation of the p53 gene at exon 4 of codon 63 in the saliva of oral squamous cell carcinoma in central India: preliminary study. J Investig Clin Dent 2010, 1, 108-113, doi: 10.1111/j.2041-1626.2010.00014.x

41. Miwa Y., Mochiduki M., Nakayama H., Shibuya N., Ogawa H., Sasaki N.: Apocrine adenocarcinoma of possible sweat gland origin in a male rabbit. J Small Anim Pract 2006, 47, 541-544, doi: 10.1111/j.1748-5827.2006.00113.x.

42. Morita R., Jin M., Ogawa B., Kuwata K., Shibutani M., Mitsumori K.: A mixed apocrine gland tumor with metastases to the bone and bone marrow in a miniature poodle. J Toxicol Pathol 2010, 23, 95-98, doi: 10.1293/tox.23.95.

43. Munirajan A.K., Tutsumi-Ishii Y., Mohanprasad B.K.C., Hirano Y., Munakata N., Shanmugam G., Tsuchida N.: p53 gene mutations in oral carcinomas from India. Int J Cancer 1996, 66, 297-300, doi: 10.1002/(SICI)1097-0215(19960503)66:3<297:: AID-IJC4>3.0.CO;2-U.

44. Nasir L., Rutteman G.R., Reid S.W.J., Schulze Ch., Argyle D.J.: Analysis of p53 mutational events and MDM2 amplification in canine soft-tissue sarcomas. Cancer Lett 2001, 174, 83-89, doi: 10.1016/s0304-3835(01)00637-1.

45. Oda H., Nakatsuru Y., Imai Y., Sugimura H., Ishikawa T.: A mutational hot spot in the p53 gene is associated with hepatoblastomas. Int $\mathrm{J}$ Cancer 1995, 60, 786-790, doi: 10.1002/ijc.2910600610.

46. Okaichi K., Ide-Kanematsu M., Izumi N., Morita N., Okumura Y., Ihara M.: Variations in sensitivity to ionizing radiation in relation to p53 mutation point. Anticancer Res 2008, 28, 2687-2690.

47. Olivier M., Hollstein M., Hainaut P.: TP53 mutations in human cancers: origins, consequence and clinical use. Cold Spring Harb Perspect Biol 2010, 2, a001008, doi: 10.1101/cshperspect. a001008. 
48. Osaki T., Kodate M., Nakanishi R., Mitsudomi T., Shirakusa T.: Surgical resection for pulmonary metastases of sweat gland carcinoma. Thorax 1994, 49, 181-182, doi: 10.1136/thx.49.2.181.

49. Pacholczyk M., Czernicki J., Ferenc T.: The effect of solar ultraviolet radiation (UVR) on induction of skin cancers (in Polish). Medycyna Pracy 2016, 67, 255-266, doi:10.13075/mp.5893.00342.

50. Park M.-H., Jung J.-Y., Jo S.-H., Kim J.-H., Lee J.-Y., Lee M.-K.: Apocrine sweat gland adenocarcinoma in a cat. Korean J Vet Res 2010, 49, 157-161

51. Pfeifer G.P., Denissenko M.F., Olivier M., Tretyakova N., Hecht S. S., Hainaut P.: Tobacco smoke carcinogens, DNA damage and p53 mutations in smoking-associated cancers. Oncogene 2002, 21, 7435-7451, doi: 10.1038/sj.onc.1205803.

52. Pfeifer G.P., You Y.-H., Besaratinia A: Mutations induced by ultraviolet light. Mutat Res-Fund Mol M 2005, 571, 19-31, doi: 10.1016/j.mrfmmm.2004.06.057.

53. Phaneendra M.S.S.V., Veena P., Saibaba M., Prasad W.L.N.V.: Apocrine gland adenocarcinoma of tail in a buffalo calf (Bubalus bubalis) - a case report. J Livest Sci 2016, 7, 165-167.

54. Rünger T.M.: $\mathrm{C} \rightarrow \mathrm{T}$ Transition mutations are not solely UVB-signature mutations, because they are also generated by UVA. J Invest Dermatol 2008, 128, 2138-2140, doi: 10.,1038/jid.2008.165.

55. Saucedo M.O., Rodriguez S.H.S., Flores C.F.A., Valenzuela R.B., Luna M.A.L.: Effects of ultraviolet radiation (UV) in domestic animals. Review. Rev Mex Cienc Pecu 2019, 10, 416-432, doi: 10.22319/rmcp.v10i2.4648.

56. Simko E., Wilcock B.P., Yager J.A.: A retrospective study of 44 canine apocrine sweat gland adenocarcinomas. Can Vet J 2003, $44,38-42$.

57. Sukhija H., Krishnan R., Balachander N., Raghavendhar K., Ramadoss R., Sen S.: C-deletion in exon 4 codon 63 of p53 as a molecular marker for oral squamous cell carcinoma: A preliminary study. Contemp Clin Dent 2015, 6, 227-234, doi: 10.4103/0976-237X.166840.
58. Takata M., Hashimoto K., Mehregan P., Lee M.W., Yamamoto A., Mohri S., Ohara K., Takehara K.: Genetic changes in sweat gland carcinomas. JCP 2000, 27, 30-35, doi:10.1034/j.16000560.2000.027001030.x

59. Tang R., Wang P.-F., Wang H.-Ch., Wang J.-Y., Hsieh L.-L.: Mutations of p53 gene in human colorectal cancer: distinct frameshifts among populations. Int J Cancer 2001, 91, 863-868, doi: 10.1002/1097-0215(200002)9999:9999<::aid-ijc1124>3.0.co;2-q.

60. Tessele B., Rissi D.R., Langohr I.M., Vielmo A., Barros C.S.L.: Mixed apocrine adenocarcinoma of the tail in a cow. Braz $\mathrm{J}$ Vet Pathol 2015, 8, 72-75.

61. Teifke J.P., Löhr C.V.: Immunohistochemical detection of p53 overexpression in paraffin wax-embedded squamous cell carcinoma of cattle, horses, cats and dogs. J Comp Path 1996, 114, 205-210, doi: 10.1016/s0021-9975(96)80010-7.

62. Villanueva A., Hoshida Y.: Depicting the role of TP53 in hepatocellular carcinoma progression. J Hepatol 2011, 55, 724-725, doi: 10.1016/j.jhep.2011.03.018.

63. Vučinić I., Stojadinović T., Mikez Z.B., Danić D., Coha B.: Apocrine carcinoma of the scalp with aggressive clinical course A case report and review of the literature. Coll Antropol 2012, 36, 209-212.

64. Woo H.G., Wang X.W., Budhu A., Kim Y.H., Kwon S.M., Tang Z.-Y., Sun Z., Harris C.C., Torgeirsson S.S.: Association of TP53 mutations with stem cell-like gene expression and survival of patients with hepatocellular carcinoma. Gastroenterology 2011, 140, 1063-1070.e8, doi: 10.1053/j.gastro.2010.11.034.

65. Ziegler A., Jeffell D.J., Kunala S., Sharma H.W., Gailani M., Simo J.A., Halperin A.J., Baden H.P., Shapiro P.E., Bale A.E., Brash D.E.: Mutation hotspots due to sunlight in the p53 gene of nonmelanoma skin cancers. Proc Natl Acad Sci 1993, 90, 4216-4220, doi: 10.1073/pnas.90.9.4216.

66. Żebracka A., Matysiak M., Durda-Jastrzębska M., Kapka-Skrzypczak L.: Molecular and environmental aspects of skin cancers. J Pre-Clin Clin Res 2015, 9, 158-162, doi: 10.5604/18982395.1186-498. 